IP Periodica Polytechnica

Social and Management

Sciences

23(2), pp. 121-132, 2015

DOI: $10.3311 /$ PPso. 7506

Creative Commons Attribution (i)

RESEARCH ARTICLE

\section{Sustainability Assessment of Hungarian Lakeside Tourism Development}

\author{
Anna Boglárka Pomucz ${ }^{1 *}$, Mária Csete ${ }^{1}$
}

Received 30 April 2014; accepted after revision 05 September 2014

\begin{abstract}
Lakeside tourism plays a vital role in Hungary's tourism, more than $20 \%$ of the guest nights in Hungary spent at the country's four lakeside destinations. These lakes have very different impacts on sustainability efforts, as their natural, social, economic and tourism characteristics are very different. Therefore, they also require tailor-made approaches to their development. In this paper, the tourism products which are planned to be developed at these tourism areas are considered to be the basis of the evaluation in terms of sustainability. A system of economic, social and environmental criteria used for the assessment and the result of the process is compared with the vulnerability of the supply types of the destinations. With this methodology, the best possible pathways toward sustainable tourism development can be determined in the regions and the key criteria can be determined, which are the most important at the comparison of the different supply types.
\end{abstract}

\section{Keywords}

sustainability assessment, lakeside tourism, sustainability, multi criteriaanalyses, tourism supply types

\footnotetext{
${ }^{1}$ Department of Environmental Economics, Faculty of Economic and Social Sciences, Budapest University of Technology and Economics, Magyar tudósok krt. 2., H-1117 Budapest, Hungary

*Corresponding author, e-mail: pomucz@eik.bme.hu
}

\section{Introduction}

In the distant past, water was important for human survival, as potable water, or for irrigation in agriculture; over time, the use of fresh water has changed, and has been gradually supplemented by ever-newer means of use. Nowadays it has become a key resource for both the industrial sector and tourism. In case of tourism, surface waters are some of the most important natural assets, and they can be the main tourism attraction of a destination anywhere in the world (Duda-Gromada et al., 2010). Because of a wide range of available activities - including bathing, sports, fishing, etc., all of which are important for tourists and locals alike - some of the world's major tourist destinations are on the waterfront (Ronade, 2008) as well as in Hungary. During the last few years, as a consequence of the changing demand and supply trends, the improvement of nearby attractions and facilities, which are independent of the water, have been given more emphasis. However, during these developments, the importance of environmental protection has remained understated. It is therefore important that during both the decision-making process and the realization of development, the principles of sustainable development are taken into consideration (Sulyok, 2012).

In this paper, the tourism of Hungary's four most important lakeside tourist destinations - at Lake Balaton, Lake Velence, Lake Fertő and Lake Tisza - are introduced and assessed through a multi criteria analysis. This type of tourist destinations are a cornerstone of the Hungarian tourism industry, with approximately one-fifth of the guest nights in Hungary spent at two of these four lakeside destinations, - at Lake Balaton and Lake Tisza, - which are independent tourism regions (Hungarian Tourism Plc, 2014). The assessment of the sustainability of tourism product development and tourism types, which are included in the tourism development programmes at their respective lakeside regions, are key elements to the transformation of tourism in a region to a sustainable path. The results of the sustainability assessment are compared with products in aspect of a lake and with the products of the other lakeside destinations in Hungary as well. With these results, key assessment criteria can be determined, which diverge consistently in case of determined products. 


\section{Sustainable tourism at lakeside destinations}

Our natural environment often provides opportunity (Lundberg and Fredman, 2012) and attractions for tourism, and in turn, tourism also has notable impacts on the environment, therefore there is a continuous interaction between them. According to Gössling (2002) the environmental consequences of tourism can be categorised into the following six groups: (1) the changes of land cover and use, (2) change in energy use, (3) extinction of wild species and the danger of biotic exchange, (4) exchange and dispersion of diseases all over the world, (5) changes in human-environmental relations, (6) consequences connecting to water use. Thus, the preservation of water bodies, such as lakes, which can be the main assets of tourism destinations, is a key element of tourism development. However, the preservation of water assets is not enough to take into consideration during the development of tourism; this process needs integrated approaches to take into consideration hydrological, social, economic and ecological interdependencies (Doulgeris et al., 2012). The integrated approach is also necessary because any kind of tourism can have positive or negative impacts on the social, economic and natural environment of the destination (Priskin, 2001; Logar, 2010) so they cause effect on all the three pillars of sustainability.

The idea of sustainability - with both the economic, social and environmental aspects considered - came to the forefront of the tourism sector in the mid-1990s (Weaver, 2010) as a reaction to the impact of the growth in the sector during the previous decades (Gössling, Scott, 2012). Since that, several documents and guide books have been created, which are covering this topic as a global issue; notable examples by the UNEP and UNWTO (2005) or UNWTO (2013), or on the European level by the Europarc Federation (2010) and the European Commission's Tourism Sustainability Group (2007). Along with that, the possible effects and consequences of climate change on tourism also came to the forefront of research. Like sustainability, climate change is brought ever more frequently into the discussion (Für and Csete, 2010) - and this is why the outcomes of sustainability and vulnerability assessments are compared in this paper.

Tourism is a dynamically changing system, integrated into their socio-economic and natural environment, but the development of the sector and the emissions of related greenhouse gases prevent it from becoming sustainable from the aspect of climate protection (Peeters and Dubois, 2010). Therefore, a number of researchers and studies have dealt with adaptation and mitigation of climate change within this sector; for example by Scott (2010), Becken (2013), Rossello-Nadal (2014) or Csete and Pomucz (2014). In connection with mitigation, it is an important point whether tourists change their decisions about tourist destinations or habits during travels, as part of efforts for climate protection (Becken, 2013). A variety of the results of the mitigation policies can be these changes in choices. Another possible way could be through the markets, through the rising prices of various services (UNWTO and UNEP, 2008). These, and other types of economic instruments help us achieve environmental, economic and social goals (Logar, 2010). Another kind of mitigation intervention may be a change in tourism supply, such that climatically more favourable tourism products of a destination are put forward during the development processes and on the tourism market.

The former method may be used not only in tackling climate change, but also to develop a more sustainable form tourism at any destination. While in the short term (to 2020) climate change scenarios are the most relevant for topical tourism planning (Scott et al., 2007), there is also wide-spread consensus that tourism should achieve greater sustainability (Gössling et al., 2012), and to realise that the change in development policies have to commence at the earliest possible instance.

Sustainable tourism development has to support the wellbeing of local inhabitants, but like in every business, the aim of tourism is the satisfaction of the customers; in this case, tourists.This lays the foundation of success of the business (Ramachandran and Chidambaram, 2012). In addition, strategies toward sustainability must be based on both the results of analyses of local responses from the tourism sector, and on a planning and consultation process with local stakeholders (Castellini and Sala, 2010). Besides the economic and social aspect, the attitudes and behaviour of stakeholders, e.g. decision makers, towards the environment can determine whether the realisation of sustainable tourism in the destination will be a success or a failure (Iimran et al., 2014).

Summarising the above through the Deming cycle (Deming, 2000), sustainable tourism development consists of five phases: (1) diagnoses to determine the strength and weaknesses of the destinations, (2) consultation and cooperation with stakeholders, (3) planning of the process, (4) completion of strategy and action plan, (5) evaluation and improvement (Castellini and Sala, 2010). This paper aims to provide a methodology for the final phase, for the evaluation of the sustainability of the tourism decisions and products. This method is specialised for lakeside destinations as popular tourism destinations in Hungary.

\section{The lakes under examination}

The sustainability of the tourism of the four most important Hungarian lakes are examined in this paper. These are characteristically very different, but also, some similar features and problems exist. Lakeside tourism destinations differ in two crucial aspects: their administrative status and their characteristic feature of tourism attractiveness. Tourist destinations around Lake Balaton and Lake Tisza are destinations in their own right, but they are not standalone administrative units or development regions; these competences are shared with their surrounding regions. In contrast, ridings surround Lake Velence and Lake Fertö, their destinations can be defined as micro-regions. In the case of Lake Balaton and Lake Velence, the classic 3S (sea, 


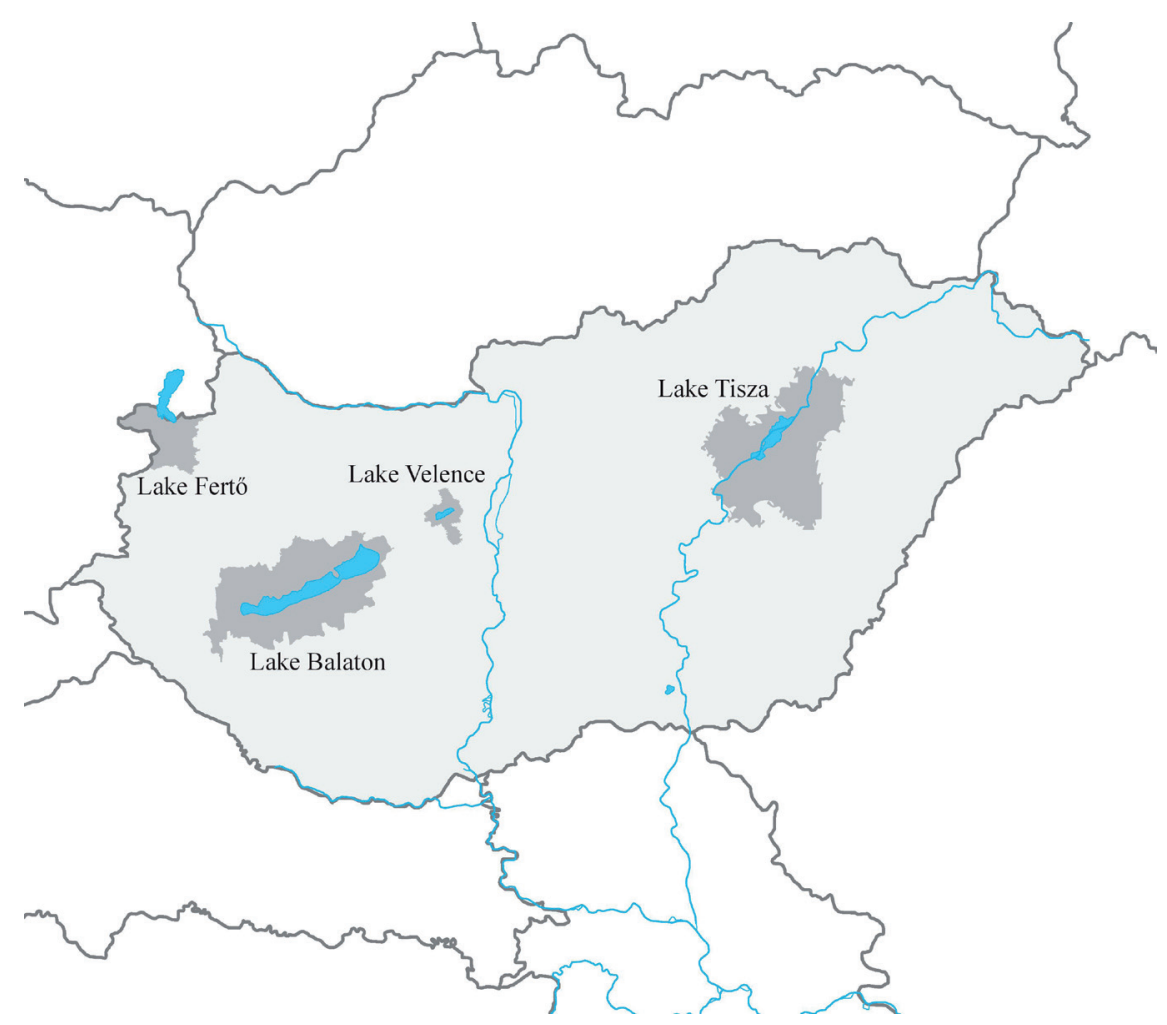

Fig. 1 The examined lakes and areas in Hungary (Source: own work)

sand, sun) tourism is the characteristic feature, in contrast with Lake Fertö and Lake Tisza, where the lakes themselves and their natural environment are the main attraction.

Figure 1 shows the location of the destinations in Hungary, facilitating the understanding of the natural particularities of the destinations and the differences in the socio-economic characteristics the various lakeside areas. Common points, best practices and the exploration and coordination of development opportunities may contribute to the development convergence of underdeveloped areas based on sustainable development, which is in line with the objectives set forth by the European Union.

All lakes are significant natural assets in Hungary, and thermal water and spas can be found around them. In spite of that, the most serious problems in all of these destinations are the short length of the season, and that all regions have financial problems regarding projects and the split of the region to shore and background areas also apply for all four lakes. The development of the infrastructure is a possible opportunity to provide better services for tourists (Aquaprofit Plc, 2006; Inn Side Ltd, 2006; LT Consort Ltd, 2005; Régiófókusz Ltd, 2006).

The lakes also have special features. Lake Balaton is the largest lake in Central Europe, with a surface of some $600 \mathrm{~km}^{2}$. Its landscape is diverse: the south shore is flat, while the north shore is hilly. The lake was once the main hub of Hungarian tourism in the $20^{\text {th }}$ century, but the number of tourists began to drop after the political changes in 1989, with the trend continuing to this day (Buday-Sántha, 2007). Nonetheless, the tourism region around the lake is still visited by a large number of tourists each year; it remains the second most visited region in Hungary, after the region of Central Hungary (i.e. the region containing Budapest) (Mester et al., 2006). Most visitors travel to Lake Balaton because of the lake itself and the closely related activities. A serious problem in the region is the lack of complex tourism products; if the weather conditions are not nice, the number of available alternatives is very limited. Perhaps the most serious problems for Lake Balaton - and also for the other three lakes - are the short season and the split between the shore and the remaining part of the region, contributing to increasing economic differences. The high-level development of tourism destination management (TDM) systems facilitates the coordination of tourism development and to solve the problems mentioned above. Furthermore, it can help strengthen domestic tourism and help establish cooperation between stakeholders (LT Consort Ltd, 2005). Not only at Lake Balaton,but also at the other lakes, the organisation of the TDM system is a convenient avenue for tourism development.

Lake Velence is the second biggest natural lake in Hungary. Its water surface is $24 \mathrm{~km}^{2}$, and with its average summer temperatures at $26-28^{\circ} \mathrm{C}$, it is one of the warmest lakes in Europe. The most significant strength of the destination is its proximity to the capital city and outstanding motorway connections, which makes it popular among domestic tourists (Priszinger, 2011). The tourismdestination around Lake Velence - like the other three - are prioritized holiday resorts in Hungary (Aubert, 2011). The lake and the micro-region around it is part of the Central Transdanubia Tourism Region. Like at Lake Balaton, the lack of cooperation and the brevity of the season are also fundamental 
problems. The split between the touristic and non-touristic part of the region is also a weakness. Financial problems festering the developments are also a weakness, and we can also mention it in the case of the following lakes (Inn Side Ltd, 2006).

Lake Fertő is Europe's second largest steppe lake (Dragonits et al., 2006) its water surface is $300 \mathrm{~km}^{2}$, but most of it is covered by reed. The lake is shared by Hungary and Austria; a quarter of it lies on Hungarian territory - which belongs to West Transdanubia Tourism Region, - while the remainder is in Austria. That is why it is often named Lake Neusiedl. The two sides of the lake are dissimilar. The Hungarian side is the centre of ecotourism - the Fertö Cultural Landscape, which is a world heritage site, - health tourism and cultural tourism, whilst the Austrian side is popular due to water tourism. In this paper, only the Hungarian part of the lake is examined. This area is also popular due to thermal water, like the former two lakes. Problems in the destination include the poor infrastructural conditions around the attraction and the lack of funds at the micro-region for further development (Régiófókusz Ltd, 2006).

Lake Tisza compared to the other examined areas is not a natural lake. It is the largest artificial in Hungary that was created in 1973 as a reservoir (Csete et al., 2013; Michalkó, 2005; Remenyik, 2009). It is also well known asfishing lake with unique natural assets in Hungary. The destination around the lake is a tourism region in itself, and it is popular among domestic tourists (Michalkó, 2005) as its rural and ecotourism facilities are well-developed. Its bird reserve is part of the Hortobágy National Park and the area is unique natural resources at European level. The lake is also popular because of fishing, but the decreasing fish stocks can cause a catastrophe. Health and business tourism and the development of cycle paths may trigger a new period for the tourism of the area. Financial problems of developments and the decrease in the stock of fish are a weakness in the region in addition the natural environment is highly vulnerable in the region (Aquaprofit Plc, 2006).

Nowadays, the expected effects of climate change on various economic sectors, such as tourism, are increasingly researched (Csete and Péterné Baranyi, 2012) thus in this paper, the results of this sustainability investigation and a previous vulnerability assessment are briefly compared. The vulnerability of the lakes and their natural surroundings is a serious threat and therefore important at the development decisions.

A previous assessment which has described climate change vulnerability (Fig. 2) as a complex indicator, integrating exposure, climate sensitivity and adaptive capacity, has concluded that Lake Balaton has a medium vulnerability (higher exposure, relatively good adaptive capacity) and Lake Tisza is far more vulnerable (higher exposure, weaker adaptive capacity), but their main attraction, the lake and river tourism, are the most vulnerable in both cases. In the region of Western Transdanubia, where Lake Fertő is situated, the most vulnerable activities connected to the lake area are outdoor event-based tourism and lake and river tourism. Similar results can be found in the Central Transdanubia Region, the region where Lake Velence belongs to. Western Transdanubia also has medium vulnerability (medium exposure and high adaptive capacity), but Central Transdanubia's vulnerability is somewhat higher than that (Csete et al., 2013).

\section{The assessed tourism products and supply types}

The Lake Balaton Concept and the Programme of Tourism Development include four groups of programmes and actions for tourism development. One of these is the development of complex tourism products. In that category, some twenty tourism products are included, which are assessed with the criteria system

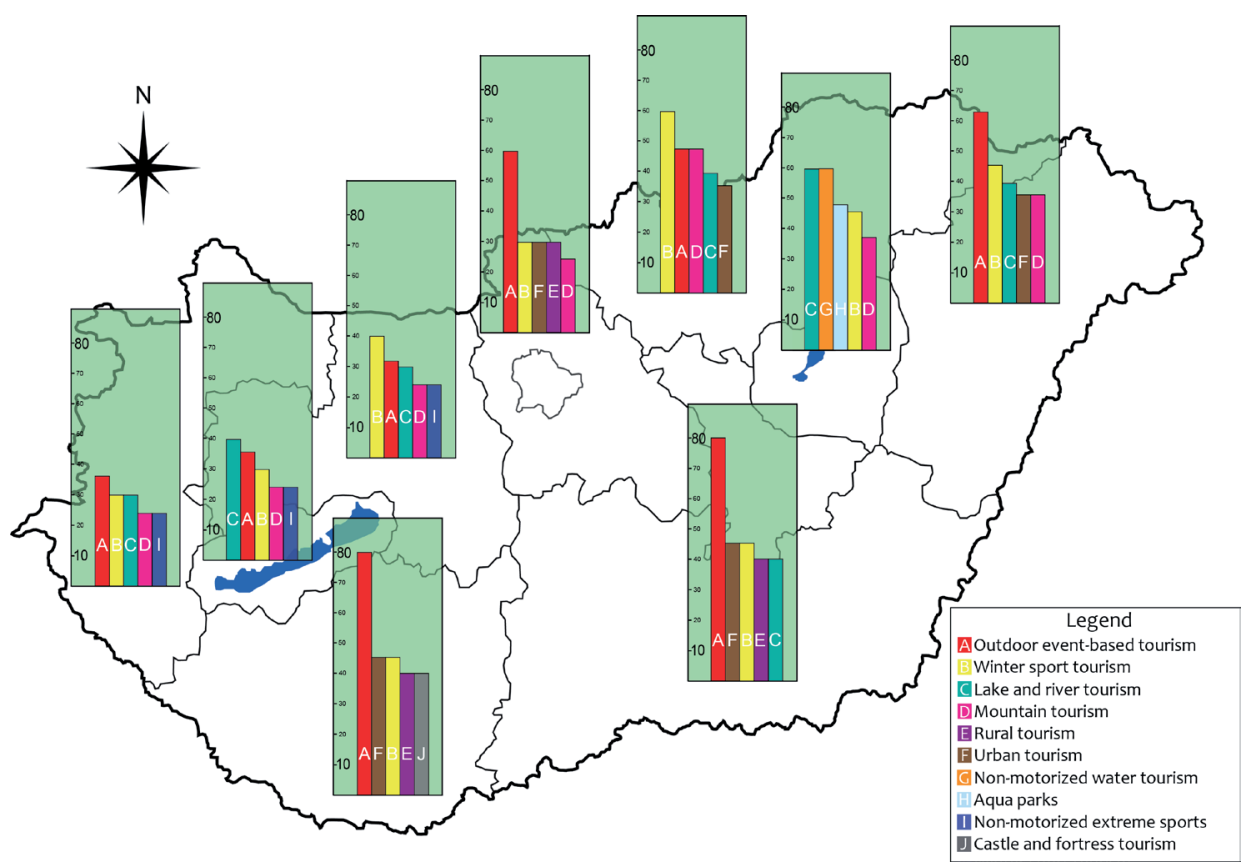

Fig. 2 Vulnerability map of Hungarian tourism regions (Source: (Csete et al., 2013)) 
Table 1 The assessed development products and supply types of the four lakeside destinations

(Source: own work based on (Aquaprofit Plc, 2006; Inn Side Ltd, 2006; LT Consort Ltd, 2005; Régiófókusz Ltd, 2006))

\begin{tabular}{|c|c|c|c|}
\hline Lake Balaton & Lake Velence & Lake Fertő & Lake Tisza \\
\hline $\begin{array}{l}\text { establishing holiday villages for families with } \\
\text { little child }\end{array}$ & & family-friendly destination & \\
\hline \multicolumn{4}{|l|}{ development of ports } \\
\hline development of beaches & & & development of beaches \\
\hline \multirow[t]{2}{*}{ fishing tourism } & & & fishing tourism \\
\hline & water tourism & & water tourism \\
\hline medicinal tourism & & health tourism & health tourism \\
\hline \multicolumn{4}{|l|}{ tourism based on hot springs } \\
\hline ecotourism & & ecotourism & ecotourism \\
\hline wine and gastrotourism & & wine and gastrotourism & gastrotourism \\
\hline riding tourism & & active recreation & riding tourism \\
\hline bicycle tourism & & & bicycle tourism \\
\hline \multicolumn{4}{|l|}{ other forms of sport tourism } \\
\hline & tourism based on built heritage & & tourism based on built heritage \\
\hline \multirow[t]{2}{*}{ cultural tourism } & & cultural tourism & \\
\hline & organizing events & & organizing events \\
\hline realization of an entertaining centre & & & arts and crafts studio \\
\hline rural tourism & rural tourism & rural tourism & rural tourism \\
\hline \multirow[t]{2}{*}{ tours at the background area } & realization of hiker centers & & \\
\hline & & & hunting tourism \\
\hline tours for pensioners & & senior tourism & \\
\hline congress and incentive tourism & & business tourism & business tourism \\
\hline \multirow[t]{2}{*}{ impovement and modernization of campsites } & & & \\
\hline & youth tourism & youth tourism & \\
\hline development of Zánkai Student Olimpic Centre & & & \\
\hline implementation of new, creativ ideas & & & \\
\hline
\end{tabular}

(LT Consort Ltd, 2005). The tourist destination at Lake Velence is not an independent tourism region and doesn't have its own tourism development programme. In this way the relevant tourism products and supply types have been selected from the Tourism Development Strategy of the Central-Transdanubia Region (Inn Side Ltd, 2006). The case of Lake Fertö is similar to Lake Velence. Its programme has been selected from Tourism Development Strategy of West-Transdanubia Tourism Region (Régiófókusz Ltd, 2006). There are three main priorities in Tourism Development Strategy of Lake Tisza, the first one is the development of attractions and design region-specific complex tourism products, these products are assessed (Aquaprofit Plc, 2006).

As Table 1 shows, there are several types of tourism products and supply types appear as development ideas at several lakeside destinations as well. Even so, they have to be examined separately in case of each lake, since the local conditions can significantly affect the likely impacts of the developments.

\section{Methodological Approach}

In this paper, a criteria system is used to evaluate and compare the sustainability of tourism products and forms of tourism, which are in the development programmes of the destinations around the four lakes examined. This system of criteria is developed and generalized from a system of evaluation that was originally created to assess and compare the sustainability aspects of development programmes in the Lake Balaton Concept and the Programme of Tourism Development (Pomucz, 2012), thus it has now been generalized to investigate any lake. With this indicator-based evaluation method, the products of a lake with each other and with the tourism products of the other three lakes can be compared. That system of criteria was developed using a system of indicators for settlements, created by Szlávik and Csete (2004), a list of indicators of sustainable tourism by Puczkó and Rátz (2001) and the indicator list specifically for the Lake Balaton region by Pintér et al. (2008).

During the redrafting the key element of the processes is identifying appropriate indicators. Some criteria are taken into consideration during the process:

- it is important to be easily explainable, to appreciate the products' effect on the indicator and to decide easily if the effects are favourable or not,

- the aspects have to be in harmony with the three pillars of sustainable development (environment, economy and society) and the three pillars have to listed in equal weight, 
- the related effects have to summarize in one aspect and independent indicators should be used to avoid the duplication of the effects.

The new system of criteria is used to evaluate the effects of the tourism product or supply types within the development strategies based on these criteria. The method examines whether the realization of the tourism product in the strategies and the functioning of the realized activity affect the factor in the proper aspect (Pomucz, 2012). In an effect matrix, the connections between the aspect and the product have been rated as follows: $(+1)$ if the product has favourable effect on the sustainability on the destination, $(-1)$ point if it has unfavourable effect, and $(\mathrm{NR}=0)$ if there is no relevant effect at all. In case of this assessment it is not reasonable to rate the effects considering the high divergence and inequality of the examined aspects and criteria.

With the used assessment method, remarkable effects can be uncovered and with that the most and less sustainable products can be selected, in case of a defined lake and as a general rule at lakeside destinations.

Also key aspects can be chosen, that's value can signify the product's sustainability. For the assessment - based on previous examinations - 21 criteria are used, seven in relation to each dimension of sustainability. In the following, these aspects are introduced and these are in brief described in case of all aspects, what is a favourable effect in sustainable way on it, obviously their opposites are the unfavourable.

Economic aspects examined:

- volume of the incomes and local taxes from tourism (+ growing amont of incomes and taxes),

- proportion of domestic tourists (+ increaseing proportion of domestic tourists),

- number of guest-nights (+ rising number of guest-nights),

- proportion of returning guests ( + increasing proportion of returning guests,

- efficiency of development (advantages/expenses) (+ rising effeciency),

- number of new jobs created by tourism development (+ realization of new jobs in tourism),

- satisfaction of tourists (+ rising satisfaction).

Social aspects examined:

- demographic conditions, population retention capacity (+ stabilization of the population, the reversal of eldering the population),

- equal opportunities (+ improving gender and race equality, assist people with disabilities),

- preservation of local culture and traditions (+ the local specialities can be solved, not replaced with commercial ones),

- quality of life of the local inhabitants (+ better quality and opportunity of life),
- collaboration, cooperation (+ rising amount of cooperation among stakeholders),

- crime rates, medical services (+ less crimenal case, more and better health services),

- education, training (+ better opportunities for learning).

Environmental aspects examined:

- water quality of the lake and other surface and ground waters (+ improving water quality),

- landscape and view (+ better harmony with natural and man-made environment),

- air quality, noise load, GHG emissions (+ improving air quality, less noise),

- soil quality, land use (+ improving soil quality, for the conditions adequate land use, brownfield investments),

- ratio of nature reserves, biodiversity (natural capital index) (+ increasing ration of natural reserved areas, rising natural capital index),

- raising environmental awareness (+ make the local people and also the tourst more attentive for their environment)

- concentration of tourists in time and space (+ more even distribution of the tourists in time and space, longer season).

\section{The Result of the Assessment}

The assessment clearly shows that most tourism products have a positive impact on incomes from tourism and the tourists' satisfaction - that applies to all of the destinations - so they have positive impact on the test region in economic terms. Product specifically one, two or sometimes more positive economic impacts are recognised, also at some products which are attractive for foreign tourists, negative affect are recognised at the aspect: "proportion of domestic tourists". Only at this aspect can be negative economic effect determined.

Since the economic effects are mostly favourable, the social and environmental factors show the extent to the sustainability of the given tourism type. Negative social impacts are hardly identified, but the favourable effects are very diverse.The developments can have a mostly positive impact of preserving the cultural values, of the demographic conditions of the destination and of the quality of life of the local inhabitants.

In the case of the investigated tourism types, negative effects are more significant at the environmental aspects. At these aspects appeared most mixed the favourable and unfavourable effects according not only the type of the tourism product but also the location.

The effect matrices have been made for all the four lakes. It is important that the following specifications are not the sustainable hierarchy of the products. They only indicate the potential favourable and unfavourable impacts, the occurring threats of the development products. Necessarily these assessment help to categorised the product which must be handled with care - and require considerable circumspection, - or which can be 
Table 2 The assessment of the tourism products refer to the Lake Balaton Tourism Region (Source: own work)

\begin{tabular}{|c|c|c|c|c|c|c|c|c|c|c|c|c|c|c|c|c|c|c|c|c|c|c|c|}
\hline & 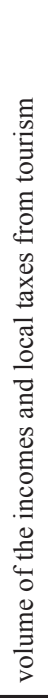 & 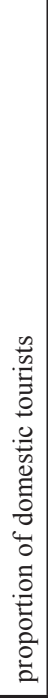 & 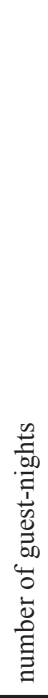 & 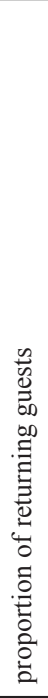 & 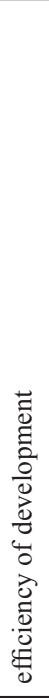 & 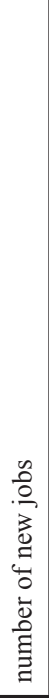 & 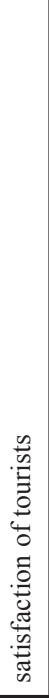 & 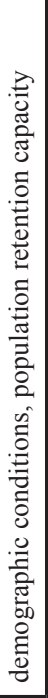 & 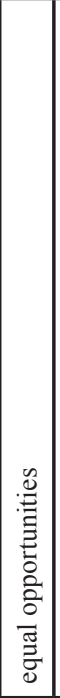 & 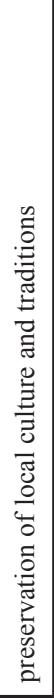 & 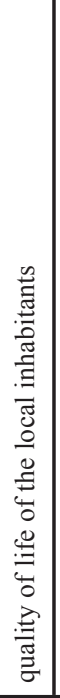 & 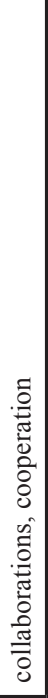 & 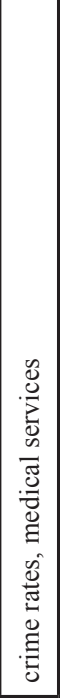 & 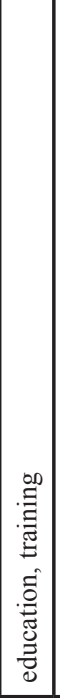 & 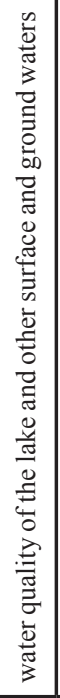 & 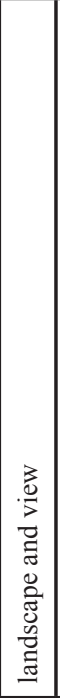 & 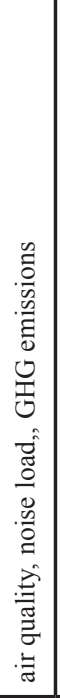 & 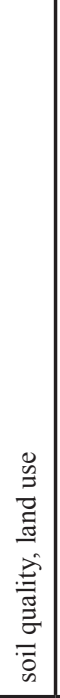 & 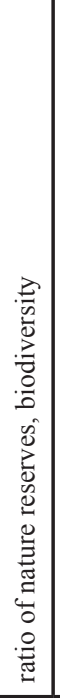 & 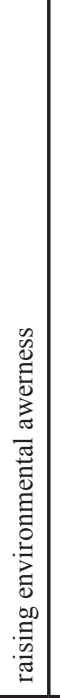 & 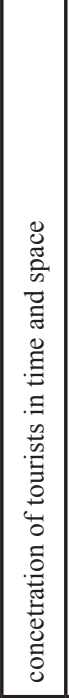 & 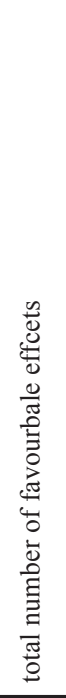 & 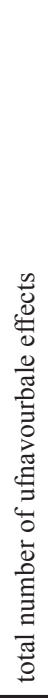 \\
\hline holiday villages & 1 & 0 & 0 & 0 & 0 & 0 & 1 & 1 & 0 & 0 & 0 & 0 & 0 & 0 & 0 & 0 & -1 & 0 & 0 & 0 & 0 & 3 & 1 \\
\hline development of ports & 1 & 0 & 0 & 1 & 0 & 0 & 1 & 0 & 0 & 0 & 0 & 0 & 0 & 0 & -1 & -1 & 0 & 0 & 0 & 0 & 1 & 4 & 2 \\
\hline development of beaches & 1 & 0 & 0 & 0 & 0 & 0 & 1 & 0 & 0 & 0 & 1 & 0 & 0 & 0 & -1 & -1 & 0 & 0 & 0 & 0 & -1 & 3 & 3 \\
\hline fishing tourism & 1 & 0 & 0 & 1 & 0 & 0 & 1 & 0 & 0 & 0 & 1 & 0 & 0 & 0 & -1 & \begin{tabular}{|l|}
-1 \\
\end{tabular} & 0 & 0 & 0 & 0 & 1 & 5 & 2 \\
\hline medicinal tourism & 1 & 0 & 0 & 1 & 0 & 0 & 1 & 1 & 0 & 0 & 0 & 0 & 1 & 0 & -1 & 0 & 0 & 0 & 0 & 0 & 1 & 6 & 1 \\
\hline tourism based on hot springs & 1 & 0 & 0 & 0 & 0 & 0 & 1 & 1 & 0 & 0 & 1 & 0 & 0 & 0 & 0 & 0 & -1 & 0 & 0 & 0 & 1 & 5 & 1 \\
\hline ecotourism & 1 & 0 & 0 & 0 & 0 & 1 & 1 & 0 & 0 & 1 & 0 & 0 & 0 & 1 & 0 & 0 & 0 & 0 & 1 & 1 & 1 & 8 & 0 \\
\hline wine and gastro tourism & 1 & 0 & 0 & 0 & 0 & 0 & 1 & 1 & 0 & 0 & 0 & 1 & 0 & 0 & 0 & 0 & 0 & 0 & 0 & 0 & 1 & 5 & 0 \\
\hline riding tourism & 1 & 0 & 0 & 0 & 0 & 0 & 1 & 1 & 0 & 1 & 0 & 0 & 0 & 0 & 0 & 0 & 0 & 0 & 0 & 1 & 1 & 6 & 0 \\
\hline bicycle tourism & 1 & 0 & 0 & 0 & 0 & 1 & 1 & 1 & 0 & 0 & 0 & 0 & 0 & 0 & 0 & 0 & 0 & 0 & 0 & 1 & 1 & 6 & 0 \\
\hline other forms of sport tourism & 1 & 0 & 0 & 0 & 0 & 0 & 1 & 1 & 0 & 0 & 1 & 0 & 0 & 0 & 0 & \begin{tabular}{|l|l}
-1 \\
\end{tabular} & -1 & 0 & 0 & 0 & 1 & 5 & 2 \\
\hline cultural tourism & 1 & 0 & 0 & 0 & 0 & 0 & 1 & 1 & 0 & 1 & 0 & 0 & 0 & 0 & 0 & 0 & -1 & 0 & 0 & 0 & 1 & 5 & 1 \\
\hline entertaining centre & 0 & 0 & 0 & 1 & 0 & 0 & 1 & 0 & 0 & 0 & -1 & 0 & 0 & 0 & 0 & \begin{tabular}{|l|}
-1 \\
\end{tabular} & -1 & 0 & 0 & 0 & 0 & 2 & 3 \\
\hline rural tourism & 1 & 0 & 1 & 0 & 0 & 1 & 1 & 1 & 0 & 1 & 1 & 1 & 0 & 0 & 0 & 0 & 0 & 0 & 0 & 0 & 1 & 9 & 0 \\
\hline tours at the background area & 1 & 0 & 0 & 0 & 0 & 0 & 1 & 1 & 0 & 1 & 0 & 0 & 0 & 0 & 0 & 0 & 0 & 0 & 0 & 0 & 1 & 5 & 0 \\
\hline tours for pensioners & 1 & -1 & 1 & 0 & 1 & 0 & 1 & 0 & 0 & 0 & 0 & 0 & 1 & 0 & 0 & 0 & 0 & 0 & 0 & 0 & 1 & 6 & 1 \\
\hline congress and incentive tourism & 1 & 0 & 1 & 0 & 0 & 0 & 1 & 0 & 0 & 0 & 0 & 0 & 0 & 0 & 0 & 0 & -1 & 0 & 0 & 0 & 1 & 4 & 1 \\
\hline development of campsites & 1 & 0 & 0 & 0 & 1 & 0 & 1 & 0 & 0 & 0 & 0 & 0 & 0 & 0 & 0 & 0 & -1 & 1 & 0 & 0 & 0 & 4 & 1 \\
\hline Zánkai Student Olimpic Centre & 1 & 0 & 0 & 1 & 0 & 0 & 1 & 0 & 1 & 0 & 0 & 0 & 0 & 1 & 0 & 0 & 0 & 0 & 0 & 1 & 1 & 7 & 0 \\
\hline new, creativ ideas & 1 & 0 & 0 & 0 & 0 & 0 & 1 & 1 & 0 & 0 & 0 & 0 & 0 & 0 & 0 & 0 & 0 & 0 & 0 & 0 & 1 & 4 & 0 \\
\hline total number of favourable effects & 19 & 0 & 3 & 5 & 2 & 3 & 20 & 11 & 1 & 5 & 5 & 2 & 2 & 2 & 0 & 0 & 0 & 1 & 1 & 4 & 16 & & \\
\hline total number of unfavourable effects & 0 & 1 & 0 & 0 & 0 & 0 & 0 & 0 & 0 & 0 & 1 & 0 & 0 & 0 & 4 & 5 & 7 & 0 & 0 & 0 & 1 & & \\
\hline
\end{tabular}

essentially sustainable. In Table 2 the assessment of the tourism products of the Lake Balaton Tourism Region are found.

Rural tourism has the most favourable effects in this assessment system, and is followed by eco-tourism. They both have favourable impacts in economic term, difference is that ecotourism gets more $(+1)$ for environmental factors, but the social impacts of rural tourism are more favourable. They are followed by the Youth Olympic Centre Zánka - which has positive impacts for equal opportunity, for education and also for some environmental category - and the rider and cycling tourism - which have favourable economic effects and further they would solve the demographic problems. Their limited adverse effects, raising environmental awareness and efforts to prolong the season are beneficial from an environmental point of view.
Products that previous mentioned can be classified as the group of sustainable products. In this category not only the numerous positive effect are important but that the positive impacts possibly show on all three pillars. Other products which get only $(+1)$ or (0) points are less favourable but don't have extremely positive effects. The tourism products which have one or more unfavourable effects at the criteria system require considerable circumspection and the possibility of the realization have be weighed up examining the expected positive and negative effects. These categories can be determined in case of all lakes.

There is only one product which get (-1) point in economic view - tours for pensioners - because it is more attractive for foreign tourists than inland tourists. In social point of view the realization of an entertaining centre is unfavourable since it 
Table 3 The assessment of the tourism products refer to the tourism destination about Lake Velence (Source: own work)

\begin{tabular}{|c|c|c|c|c|c|c|c|c|c|c|c|c|c|c|c|c|c|c|c|c|c|c|c|}
\hline & 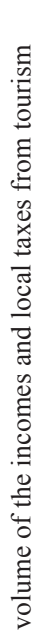 & 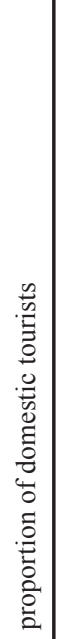 & 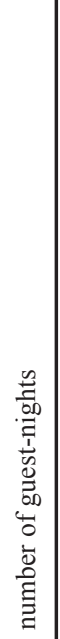 & 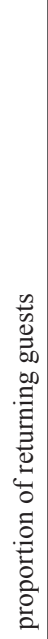 & 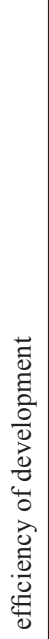 & 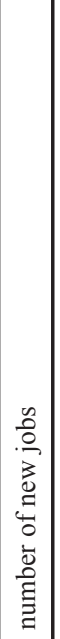 & 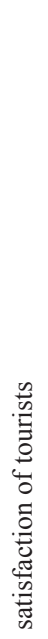 & 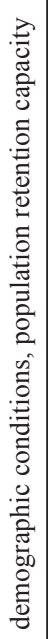 & 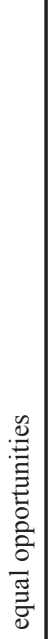 & 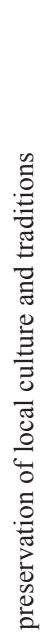 & 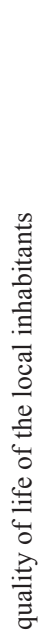 & 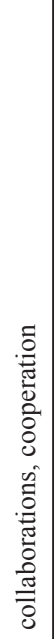 & 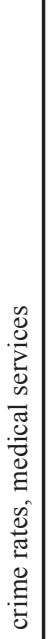 & 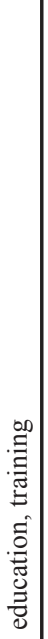 & 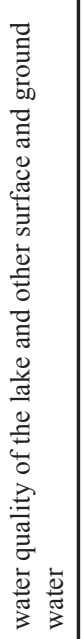 & 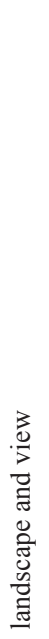 & 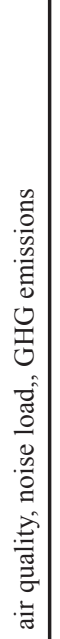 & 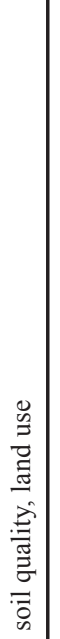 & 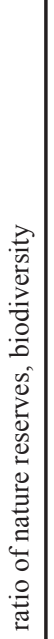 & 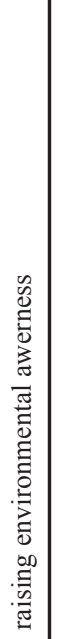 & 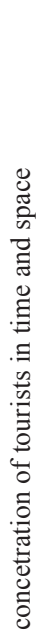 & 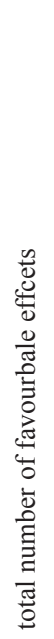 & 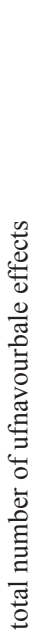 \\
\hline realization of hiker centers & 1 & 1 & 1 & 0 & 0 & 1 & 1 & 0 & 0 & 0 & 0 & 0 & 0 & 0 & 0 & 1 & 0 & 0 & 0 & 1 & 0 & 7 & 0 \\
\hline organizing events & 1 & 1 & 1 & 1 & 0 & 0 & 1 & 0 & 0 & 0 & 0 & 1 & 0 & 0 & 0 & 0 & 0 & 0 & 0 & 0 & 0 & 6 & 0 \\
\hline tourism based on built heritage & 1 & 0 & 1 & 0 & 1 & 1 & 0 & 0 & 0 & 0 & 0 & 0 & 0 & 0 & 0 & 0 & -1 & 0 & 0 & 0 & 0 & 4 & 1 \\
\hline water tourism & 1 & 0 & 1 & 0 & 0 & 1 & 1 & 0 & 0 & 0 & 0 & 0 & 0 & 0 & 1 & 0 & 0 & 0 & 0 & 0 & 1 & 6 & 0 \\
\hline rural tourism & 1 & 0 & 0 & 0 & 0 & 1 & 1 & 1 & 0 & 1 & 1 & 1 & 0 & 0 & 0 & 0 & 0 & 0 & 0 & 0 & 0 & 7 & 0 \\
\hline youth tourism & 1 & 0 & 1 & 1 & 0 & 0 & 1 & 0 & 0 & 0 & 0 & 0 & 0 & 0 & 0 & 0 & 0 & 0 & 0 & 0 & 0 & 4 & 0 \\
\hline total number of favourable effects & 6 & 2 & 5 & 2 & 1 & 4 & 5 & 1 & 0 & 1 & 1 & 2 & 0 & 0 & 1 & 1 & 0 & 0 & 0 & 1 & 1 & & \\
\hline total number of unfavourable effects & 0 & 0 & 0 & 0 & 0 & 0 & 0 & 0 & 0 & 0 & 0 & 0 & 0 & 0 & 0 & 0 & 1 & 0 & 0 & 0 & 0 & & \\
\hline
\end{tabular}

can confuse the local inhabitants for example the noise or the traffic further this tourism product has other negative impacts that is why it is unsustainable. Other products have unfavourable environmental effects for example holiday villages, ports, beach tourism etc. due to large investment needs. In case of beaches, the natural environment is overloaded and this type of recreation strengthens the seasonality.

Six tourism products are mentioned in the development programmes of the tourism region where Lake Velence belongs, relating to the lake and the destinations around it. Table 3 represents the results of the assessment.

Four of the six assessed programmes have several favourable effects - but mostly only on two pillars. The programme, realization of hiker centres, has positive effects on the economy and less for environmental aspects. Rural tourism is favourable from economic and social considerations - like at Lake Balaton - and also like event tourism. Water tourism like every product and supply type has positive economic effects and causes positive effects on water quality and to extend the season.

Youth tourism can be classified in the temporary category because it has favourable effects but only I economic point of view. So it is not problematic, but don't have remarkable effects on the sustainability of the region.

The judgement of tourism based on built heritages is uncertain while it does not influence the social processes in any significant way, and the renovation of the buildings can cause unfavourable effects in environmental point of view.
The examination of the priority tourism types present in the tourism region of Lake Fertő can be seen on Table 4.

At Lake Fertö, ecotourism, rural tourism, and wine and gastro tourism proves to be the most sustainable because they have favourable effects on the local society - quality of life and local cooperation - and the natural environment in the area. The difference between the three tourism products is the distribution of the positive impacts among the economic and environmental pillars.

Youth tourism - like at Lake Velence - and family friendly tourism belong to the temporary category. Senior and cultural tourism cannot be clearly classified. Senior tourism has less positive impacts as the former products but they are favourable in the view of ell of the pillars. In contrast cultural tourism has more favourable effects, but only in economic and social aspect. Their categorizations need substantive examination.

Active tourism, including cycling, water, horse riding, golf, hunting etc. appear to have unfavourable effects in the region because some products from this group have harmful effects during the necessary development processes. Health and business tourism also have this negative environmental impacts, since they have several positive effects in economic and social aspects their realization need particular exmination.

The tourism products in Table 5 connect to the priorities of the development strategy of Lake Tisza tourism region.

At Lake Tisza, the tourism products are similar to those at Lake Balaton: the most sustainable tourism products are rural 
Table 4 The assessment of the tourism products refer to the tourism destination about Lake Fertő (Source: own work)

\begin{tabular}{|c|c|c|c|c|c|c|c|c|c|c|c|c|c|c|c|c|c|c|c|c|c|c|c|}
\hline & 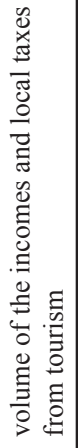 & 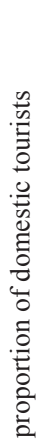 & 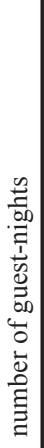 & 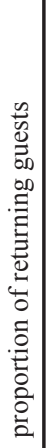 & 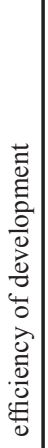 & 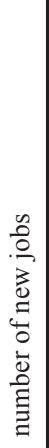 & 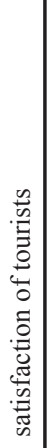 & 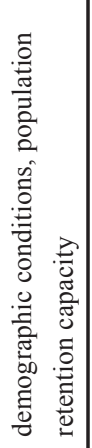 & 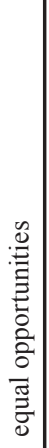 & 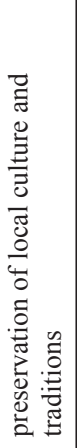 & 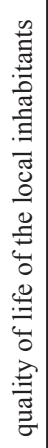 & 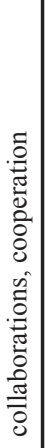 & 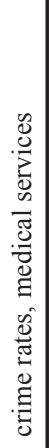 & 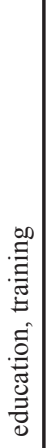 & 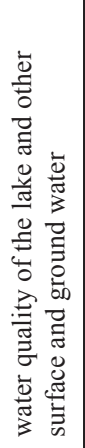 & 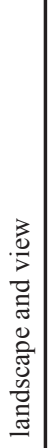 & 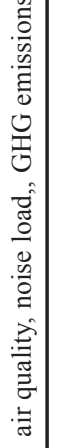 & 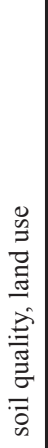 & 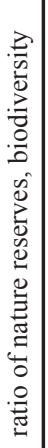 & 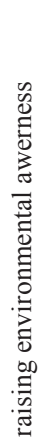 & 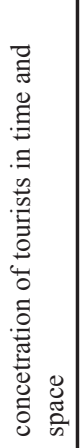 & 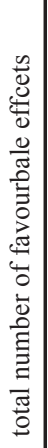 & 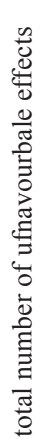 \\
\hline health tourism & 1 & 0 & 1 & 1 & 0 & 0 & 1 & 0 & 0 & 0 & 1 & 1 & 1 & 1 & 0 & 0 & -1 & 0 & 0 & 0 & 0 & 8 & 1 \\
\hline ecotourism & 0 & 0 & 0 & 0 & 0 & 0 & 1 & 0 & 0 & 1 & 1 & 1 & 0 & 1 & 0 & 1 & 0 & 0 & 1 & 1 & 0 & 8 & 0 \\
\hline cultural tourism & 1 & 0 & 1 & 0 & 1 & 0 & 1 & 0 & 0 & 1 & 1 & 0 & 0 & 0 & 0 & 0 & 0 & 0 & 0 & 0 & 0 & 6 & 0 \\
\hline family-friendly destination & 1 & 0 & 0 & 1 & 0 & 0 & 1 & 0 & 0 & 0 & 1 & 0 & 0 & 0 & 0 & 0 & 0 & 0 & 0 & 0 & 0 & 4 & 0 \\
\hline youth tourism & 0 & 1 & 0 & 1 & 0 & 0 & 1 & 0 & 0 & 0 & 1 & 0 & 0 & 0 & 0 & 0 & 0 & 0 & 0 & 0 & 0 & 4 & 0 \\
\hline senior tourism & 1 & 0 & 1 & 0 & 0 & 0 & 1 & 0 & 0 & 0 & 0 & 0 & 1 & 0 & 0 & 0 & 0 & 0 & 0 & 0 & 1 & 5 & 0 \\
\hline rural tourism & 1 & 0 & 0 & 0 & 0 & 1 & 0 & 1 & 0 & 0 & 1 & 1 & 0 & 0 & 0 & 1 & 0 & 0 & 0 & 0 & 0 & 6 & 0 \\
\hline active recreation & 1 & 0 & 0 & 0 & 0 & 0 & 1 & 0 & 0 & 0 & 1 & 0 & 1 & 0 & 0 & 0 & -1 & 0 & 0 & 0 & 0 & 4 & 1 \\
\hline wine and gastro tourism & 1 & 0 & 0 & 0 & 0 & 1 & 1 & 0 & 0 & 1 & 1 & 1 & 0 & 0 & 0 & 1 & 0 & 0 & 0 & 0 & 0 & 7 & 0 \\
\hline business tourism & 1 & 0 & 0 & 1 & 1 & 0 & 1 & 0 & 1 & 0 & 0 & 0 & 0 & 1 & 0 & 0 & -1 & 0 & 0 & 0 & 1 & 7 & 1 \\
\hline total number of favourable effects & 8 & 1 & 3 & 4 & 2 & 2 & 9 & 1 & 1 & 8 & 8 & 4 & 3 & 3 & 0 & 3 & 0 & 0 & 1 & 1 & 2 & & \\
\hline $\begin{array}{l}\text { total number of funavourable } \\
\text { effects }\end{array}$ & 0 & 0 & 0 & 0 & 0 & 0 & 0 & 0 & 0 & 0 & 0 & 0 & 0 & 0 & 0 & 0 & 3 & 0 & 0 & 0 & 0 & & \\
\hline
\end{tabular}

Table 5 The assessment of the tourism products refer to the Lake Tisza Tourism Region (Source: own work)

\begin{tabular}{|c|c|c|c|c|c|c|c|c|c|c|c|c|c|c|c|c|c|c|c|c|c|c|c|}
\hline & 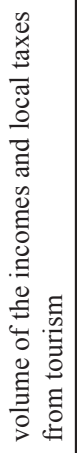 & 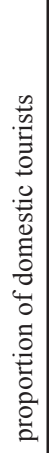 & 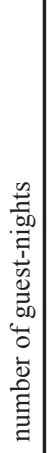 & 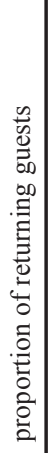 & 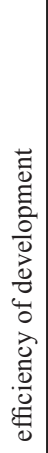 & 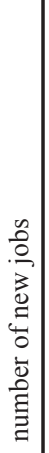 & 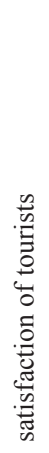 & 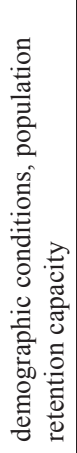 & 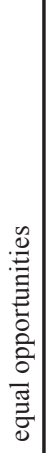 & 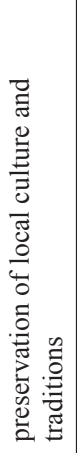 & 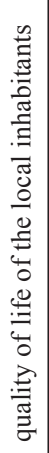 & 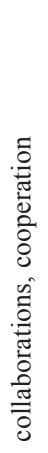 & 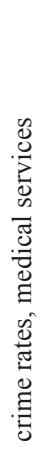 & 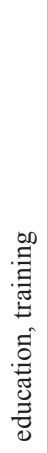 & 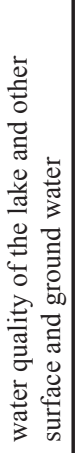 & 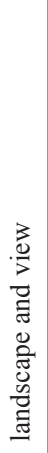 & 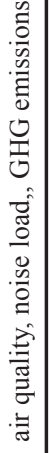 & 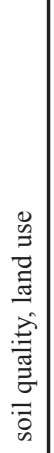 & 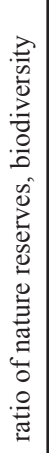 & 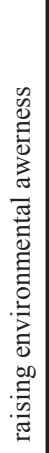 & 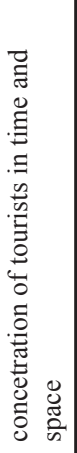 & 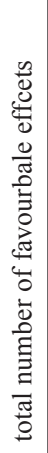 & 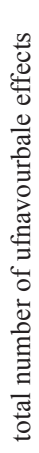 \\
\hline ecotourism & 1 & 0 & 0 & 1 & 0 & 0 & 1 & 0 & 0 & 0 & 0 & 1 & 0 & 0 & 0 & 1 & 0 & 0 & 0 & 1 & 1 & 7 & 0 \\
\hline water tourism & 1 & 0 & 0 & 0 & 0 & 0 & 1 & 0 & 0 & 0 & 0 & 0 & 0 & 0 & -1 & 0 & 1 & 0 & 0 & 0 & 0 & 3 & 1 \\
\hline development of beaches & 1 & 0 & 1 & 0 & 0 & 0 & 0 & 0 & 0 & 0 & 0 & 0 & 0 & 0 & -1 & 0 & 0 & 0 & 0 & 0 & -1 & 2 & 2 \\
\hline fishing tourism & 1 & 0 & 1 & 0 & 0 & 0 & 0 & 0 & 0 & 1 & 0 & 0 & 0 & 0 & -1 & 0 & -1 & 0 & 0 & 0 & 1 & 4 & 2 \\
\hline bicycle tourism & 1 & 0 & 0 & 0 & 0 & 0 & 1 & 1 & 0 & 0 & 0 & 0 & 0 & 0 & 0 & 0 & 1 & 0 & 0 & 1 & 1 & 6 & 0 \\
\hline health tourism & 1 & 0 & 1 & 0 & 0 & 0 & 1 & 1 & 0 & 0 & 0 & 0 & 1 & 0 & 0 & 0 & -1 & 0 & 0 & 0 & 1 & 6 & 1 \\
\hline rural tourism & 1 & 0 & 0 & 0 & 0 & 1 & 1 & 1 & 0 & 1 & 1 & 1 & 0 & 0 & 0 & 0 & 0 & 0 & 0 & 0 & 1 & 8 & 0 \\
\hline business tourism & 1 & 0 & 0 & 0 & 0 & 1 & 1 & 0 & 0 & 0 & 0 & 0 & 0 & 0 & 0 & 0 & -1 & 0 & 0 & 0 & 1 & 4 & 1 \\
\hline organizing events & 1 & 1 & 0 & 0 & 0 & 0 & 1 & 1 & 0 & 1 & 1 & 0 & 0 & 0 & 0 & 0 & 0 & 0 & 0 & 0 & 1 & 7 & 0 \\
\hline hunting tourism & 1 & -1 & 0 & 0 & 0 & 0 & 1 & 1 & 0 & 0 & 0 & 0 & 0 & 0 & 0 & 0 & 0 & 0 & -1 & 0 & 1 & 4 & 2 \\
\hline tourism based on built heritage & 0 & 0 & 0 & 0 & 0 & 0 & 1 & 1 & 0 & 1 & 0 & 0 & 0 & 0 & 0 & 1 & -1 & 0 & 0 & 0 & 1 & 5 & 1 \\
\hline gastro tourism & 0 & 0 & 0 & 0 & 0 & 0 & 1 & 0 & 0 & 1 & 1 & 0 & 0 & 0 & 0 & 0 & 0 & 0 & 0 & 0 & 0 & 3 & 0 \\
\hline riding tourism & 1 & 0 & 0 & 0 & 0 & 0 & 1 & 1 & 0 & 1 & 0 & 1 & 0 & 0 & 0 & 0 & 0 & 0 & 0 & 0 & 1 & 6 & 0 \\
\hline arts and crafts studio & 0 & 0 & 0 & 0 & 0 & 0 & 1 & 1 & 0 & 1 & 0 & 0 & 0 & 0 & 0 & 0 & 0 & 0 & 0 & 0 & 0 & 3 & 0 \\
\hline total number of favourable effects & 11 & 1 & 3 & 1 & 0 & 2 & 12 & 8 & 0 & 7 & 3 & 3 & 1 & 0 & 0 & 2 & 2 & 0 & 0 & 2 & 10 & & \\
\hline $\begin{array}{l}\text { total number of unfavourable } \\
\text { effects }\end{array}$ & 0 & 1 & 0 & 0 & 0 & 0 & 0 & 0 & 0 & 0 & 0 & 0 & 0 & 0 & 3 & 0 & 4 & 0 & 1 & 0 & 1 & & \\
\hline
\end{tabular}


tourism, ecotourism and riding tourism. The distributions of the favourable effects are parallel with the first examined lake.

At this lake also can be find the tourism types which are difficult to categorized because it has less positive impacts as the former products but they are favourable in the view of ell of the pillars - bicycle tourism - it has more favourable effects - event tourism.

A lot of tourism products have negative impacts mostly on environmental criteria. Fishing, development of beaches and water tourism unfavourable because of the disturbance of the natural environment, and the beaches contribute the seasonality. Health and business tourism and tourism based on built heritage cause negative effects - like at Lake Fertö - because of the necessarily of construction investments. Hunting tourism is not favourable for economic reasons, because of its exclusivity. The other supply types are respectable in sustainable view.

The analysis of tourism development programmes of the four Hungarian lakes in this paper have pinpointed to determine the expected effects of tourism products or types at the destinations selected. The two products which are most favourable in sustainable point of view are rural tourism and ecotourism in the Hungarian lake destination, excluding Lake Fertö, in whose case these types of development goals are not included in the strategy. These tourism supply types are not in the list of the five most vulnerable tourism types at the case of any examined lake or region (Csete et al., 2013) so the development of them are not threatened by climate change. Additionally, at Lake Balaton and Lake Velence, riding tourism, which fits well in the previous two tourism types, also received a favourable evaluation, and this is also out of the list of the most vulnerable tourism types.

There are fewer similarities among the least sustainable products. The beaches and water tourism, which are sometimes named differently, were evaluated negatively - with the exception of the Lake Velence - due to their potentially unfavourable environmental impacts. Lake and river tourism is the most vulnerable tourism type in the case of Lake Balaton and Lake Tisza and third on the list of Lake Ferto and Lake Velence (Csete et al., 2013) so the development of them is not only unfavourable in the terms of sustainability, but also critical from a climatic aspect. Other products like holiday villages and ports unfavourable because their negative environmental impacts, but hunting tourism is problematic in economic aspects. These tourism types are not extremely vulnerable, but outdoor event-based tourism is on the list of the critical - excepting Lake Tisza (Csete et al., 2013) so reflective organisation is in necessary. There is similarity in other in sustainability view problematic products for example business tourism or tourism based on built heritage because they need huge investments which can cause negative environmental impacts.

\section{Conclusions}

The assessment has definitely revealed that tourism development generates economically favourable impacts in the region - apart from a few specific exceptions. If relevant social impacts appear, they are mostly positive. At all type of tourism development, the most critical points are the environmnetal impacts, which may be both favourable and unfavourable.

Some aspects ought to be highlighted, in connection with the observed unfavourable effects - some of them return at the various lakes. This is important, since they indicate the potential dangers of a development from a sustainability aspect. Obviously, the other negative impacts encountered at other research locations are not to be ignored, but the following have made themselves known at Hungarian lakes. From the economic aspects, the "proportion of domestic tourists", which has indicated negative effect at the development, which is too exclusive and expensive for Hungarian tourists. The quality of life of the local inhabitants in the social dimension has received a negative evaluation at the development idea, that fundamentally trouble the local people in their daily lives, thus worsen the quality of life. From the environmental aspects, those connected to the quality of water, landscape, air quality and greenhouse gasses, to the biodiversity and to the concentration of the tourists, changes are most remarkable. At some aspects, typically only negative impacts appear - air quality, greenhouse gas emissions and water quality. In the case of landscape and biodiversity, a mixture of negative and positive effects are noticable. Most of the products have favourable impacts about the aspect "concentration of the tourists", only some case appear unfavorable effect, but this can be a good indicator. As a priority review can be used these criteria to draw conclusions related to sustainability.

The methodology used in this paper seems to be applicable to indicate whether the impacts of tourism products or supply types are favourable or not, and with these results, they can be categorised based on the necessity of future examination or threats. In addition, the lake-specific results and the information about the vulnerability are important in relation to development decisions, but the determination of the similarity can be useful at the examination of analogous areas.

\section{Acknowledgement}

This paper was supported by the János Bolyai Research Scholarship of the Hungarian Academy of Sciences.

\section{References}

Aquaprofit Plc. (2006) Tisza-tavi régió turizmus fejlesztési stratégiája 2007 2013. (Tourism Development Strategy of Lake Tisza 2007-2013.) [Online] Available from: http://www.kormany.hu/download/a/8e/20000/Tisza-to. pdf\#!'DocumentBrowse [Accessed: 5th February 2014] (in Hungarian)

Aubert, A. (2011) A turizmus területi lehatásolásának kérdései. In: Dávid, L. (ed.) Magyarország turisztikai régiói. Science University of Pécs. (in Hungarian) 
Becken, S. (2013) A review of Tourism and climate change as an evolving knowledge domain. Tourism Management Perspectives. 6. pp. 53-62. DOI: 10.1016/j.tmp.2012.11.006

Buday-Sántha, A. (2007) A Balaton-régió fejlesztése. (Development Issues of the Balaton Region.) Budapest:Saldo. (in Hungarian)

Castellini, V., Sala, S. (2010) Sustainable performance index for tourism policy development. Tourism Management. 31 (6). pp. 871-880. DOI: $10.1016 /$ j.tourman.2009.10.001

Csete, M., Pálvölgyi, T., Szendrö, G. (2013) Assessment of climate change vulnerability of tourism in Hungary. Regional Environmental Change. 13 (1). pp. 1043-1057. DOI: 10.1007/s10113-013-0417-7

Csete, M., Péterné Baranyi, R. (2012) Turizmusfejlesztési stratégia klímabarát nézőpontból. (Tourism development strategy from a climate-friendly perspective.) Agora. 2012 (9). pp. 97-112. (in Hungarian)

Csete, M., Pomucz, A. B. (2014) Utazási motivációk értékelése a preferált közlekedési módok CO2-kibocsátásának tükrében (The Evaluation of Tourism Motivation Logistic Based on the Carbon Footprints of the Preferred Way of Travelling.) In: Bokor, Z. (ed.) Logisztikai Évkönyv. (Logistics Yearbook.) Budapest: Magyar Logisztikai Egyesület. (in Hungarian)

Deming, W. E. (2000) The new economics: For industry, government, education. Cambridge: MIT CAES.

Doulgeris, C., Georgiou, P., Papadimos, D., Papamichail, D. (2012) Ecosystem approach to water resources management using the MIKE 11 modeling system in the Strymonas River and Lake Kerkini. Journal of Environmental Management. 94 (1). pp. 132-143.

DOI: 10.1016/j.jenvman.2011.06.023

Dragonits, E., Zámolyi, A., Hodits, B., Gier, S., Grasemann, B., Janda, C., Schiel, B., Rohatsch, A., Popp, F. (2006) Neusiedlersee/Fertő Tó area (Austria/ Hungary): landscape change through time constrained by geomorphology, lithostratigraphic sections, archaeology and historical maps. Geophysical Research Abstracts. (8) 09995. SRef-ID: 1607-7962/gra/EGU06-A-09995

Duda-Gromada, K., Bujdosó, Z., Dávid, L. (2010) Lakes, reservoirs and regional development through some examples in Poland and Hungary. GeoJournal of Tourism and Geosites. 5 (1). pp. 16-23.

Europarc Federation (2010) European charter for sustainable tourism in protected areas. [Online] Available from: http://www.european-charter.org/ become-a-charter-area/the-charter-documents [Accessed: 12th April 2014]

European Commission - Tourism Sustainabilty Group (2007) Action for more sustainable European tourism. Report of the Tourism Sustainability Group 2007. [Online] Available from: http://ec.europa.eu/enterprise/sectors/tourism/files/docs/tsg/tsg_final_report_en.pdf [Accessed: 11th April 2014]

Für, A., Csete, M. (2010) Modeling methodologies of synergic effects related to climate change and sustainable energy management. Periodica Polytechnica Social and Management Sciences. 18 (1). pp. 11-19. DOI: 10.3311 pp.so.2010-1.02

Gössling, S. (2002) Global environmental consequences of tourism. Global Environmental Change. 12 (4). pp. 283-302. DOI: 10.1016/S0959-3780(02)00044-4

Gössling, S., Hall, C. M., Ekström, F., Brudvik Engeset, A., Aall, C. (2012) Transition management: a tool for implementing sustainable tourism scenarios?. Journal of Sustainable Tourism. 20 (6). pp. 899-916. DOI: $10.1080 / 09669582.2012 .699062$

Gössling, S., Scott, D. (2012) Scenario planning for sustainable tourism: an introduction. Journal of Sustainable Tourism. 20 (6). pp. 773-778. DOI: 10.1080/09669582.2012.699064

Hungarian Tourism Plc (2014) Tourism in Hungary 2013 with preliminary data. [Online] Available from: http://at.gotohungary.com/documents/183903/1035045/Tourismus+in+Ungarn+2013+With+Prelimi nary+Data/3eadf157-da70-4196-891a-520badaf19e5 [Accessed: 17th February 2014]
Iimran, S., Alam, K., Beaumont, N. (2014) Environmental orientations and environmental behaviour: Perceptions of protected area tourism stakeholders. Tourism Management. 40. pp. 290-299.

DOI: $10.1016 / j$.tourman.2013.07.003

Inn Side Ltd (2006) Közép-Dunántúli Régió Turisztikai Fejlesztési Stratégiája (Tourism Development Strategy of Central-Transdanubia Region). [Online] Available from: http://www.kormany.hu/download/6/8e/20000/ Kuzep-Dunantul.pdf [Accessed: 5th February 2014] (in Hungarian)

Logar, I. (2010) Sustainable tourism management in Crikvenica, Croatia: An assessment of policy instruments. Tourism Management. 31 (1). pp. 125 135. DOI: 10.1016/j.tourman.2009.02.005

LT Consort Ltd (2005) Balaton turizmus fejlesztési koncepciója és programja (BTFKP) (Lake Balaton Concept and Program of Tourism Development.) [Online] Available from: http://www.kormany.hu/download/d/7e/20000/ Balaton.pdf [Accessed: 5th February 2014] (in Hungarian)

Lundberg, C., Fredman, P. (2012) Success factors and constraints among nature-based tourism entrepreneurs. Current Issues in Tourism. 15 (7). pp. 649-671. DOI: 10.1080/13683500.2011.630458

Mester, T., Polgár, J., Kiss, K. (2006) A Balatoni turizmus alakulása a statisztikák tükrében. Turizmus Bulletin. 10. pp. 63-69. (in Hungarian)

Michalkó, G. (2005) A Tisza-tó turisztikai potenciálja. (Tourism potencial of Lake Tisza). Földrajzi Értesitö. 54 (1-2). pp. 129-147. (in Hungarian)

Peeters, P., Dubois, G. (2010) Tourism travel under climate change mitigation constraints. Journal of Transport Geography. 18 (3). pp. 449-457. DOI: 10.1016/j.jtrangeo.2009.09.003

Pintér, L., Bizikova, L., Kutics K., Vári, A. (2008) Developing a system of sustainability indicators for the Lake Balaton region. Tájökológiai Lapok. 6 (3). pp. 271-293.

Pomucz, A. B. (2012) Assessment of sustainable tourism development at Lake Balaton. In: Kincseink védelmében - fenntarthatóság és környezettudatosság a turizmusban. Györ.

Priskin, J. (2001) Assessment of natural resources for nature-based tourism: the case of the Central Coast Region of Western Australia. Tourism Management. 22 (6). pp. 637-648. DOI: 10.1016/S0261-5177(01)00039-5

Priszinger, K. (2011) Közép-Dunántúl. In: Dávid, L. (ed) Magyarország turisztikai régiói. Science University of Pécs. (in Hungarian)

Puczkó, L., Rátz, T. (2001) A turizmus hatásai. Budapest: Aula. (in Hungarian) Ramachandran, A., Chidambaram, V. (2012) A review of customer satisfaction towards service quality of banking sector. Periodica Polytechnica Social and Management Sciences. 20 (2). pp. 71-79.

DOI: $10.3311 /$ pp.so.2012-2.02

Régiófókusz Ltd (2006) Nyugat-Dunántúl turisztikai Régió Turizmusfejlesztési Stratégiája 2007-2013. (Tourism Development Strategy of West-Transdanubia Tourism Region). [Online] Available from: http://www.kormany.hu/download/7/8e/20000/Nyugat-Dunantul.pdf\#!DocumentBrowse [Accessed: 5th February 2014] (in Hungarian)

Remenyik, B. (2009) Fenntartható turizmusfejlesztés a Tisza-tónál. Gazdálkodás. 53 (5). pp. 465-469. (in Hungarian)

Ronade, P. S. (2008) Managing Lake Tourism: Challenges Ahead. In:Conference on tourism in India. Kozhikoda, $15^{\text {th }}$ to $17^{\text {th }}$ May 2008.

Rossello-Nadal, J. (2014) How to evaluate the effects of climate change on tourism. Tourism Management. 42. pp. 334-340.

DOI: $10.1016 /$ j.tourman.2013.11.006

Scott, D. (2010) Why sustainable tourism must address climate change. Journal of Sustainable Tourism. 19 (1). pp. 17-34. DOI: 10.1080/09669582.2010.539694

Scott, D., Jones, B., Konopek, J. (2007) Implications of climate and environmental change for nature-based tourism in the Canadian Rocky Mountains: A case study of Waterton Lakes National Park. Tourism Management. 28 (2). pp. 570-579. DOI: 10.1016/j.tourman.2006.04.020 
Sulyok, J. (2012) Víz, amiért érdemes útra kelni. A táji környezet szerepe a vízparti utazás során. (The role of the natural environment in waterside travel destination.) Tér és Társadalom. (Space and Society). 26 (4). (in Hungarian)

Szlávik, J., Csete, M. (2004) A fenntarthatóság érvényre jutása és mérhetősége települési - kisregionális szinten. Gazdálkodás. 48 (4) pp. 10-28. (in Hungarian)

United Nations Environment Programme (UNEP), World Tourism Organization (UNWTO) (2005) Making Tourism More Sustainable: A Guide for Policy Makers.
Weaver, D. (2010) Can sustainable tourism survive climate change?. Journal of Sustainable Tourism. 19 (1). pp. 5-15.

DOI: $10.1080 / 09669582.2010 .536242$

World Tourism Organization (UNWTO) (2013) Sustainable tourism for development. [Online] Available from: http://www2.unwto.org/en/content/ sustainable-tourism-development-developing-countries-documentthree-interlinking-parts [Accessed: 21 th April 2014]

World Tourism Organization (UNWTO), United Nations Environment Programme (UNEP) (2008) Climate Change and Tourism - Responding to Global Challenges. 